\title{
Ruellia saccata, a New Species of Acanthaceae from Bolivia
}

\author{
Alexander N. Schmidt-Lebuhn \\ Institute for Systematic Botany, University of Zurich, Zollikerstrasse 107, 8051 Zurich, \\ Switzerland. alexander.schmidt-lebuhn@systbot.uzh.ch
}

\begin{abstract}
Erin A. Tripp
Duke University, Department of Biology, 137 Biological Sciences, Durham, North Carolina 27708, U.S.A. Current address: Rancho Santa Ana Botanic Garden, 1500 N. College Ave., Claremont, California 91711, U.S.A. etripp@rsabg.org
\end{abstract}

Abstract. Ruellia saccata Schmidt-Lebuhn \& E. Tripp, a new species of Acanthaceae from Beni, Bolivia, with a highly distinctive corolla morphology, is described as new to science. The novelty resembles and is related to $R$. brevifolia (Pohl) C. Ezcurra, but differs in the presence of a pronounced corolla pouch, a longer corolla with a narrower orifice, and a spreading to procumbent habit. Its differences from and similarities to other species in the genus are also discussed, and an updated key to the red-flowered Bolivian species of Ruellia L. is presented.

Resumen. Ruellia saccata Schmidt-Lebuhn \& E. Tripp, una nueva especie de Acanthaceae de Beni, Bolivia, que tiene una corola morfológicamente muy distintiva, es descrita como nueva para la ciencia. La nueva especie se asemeja y está relacionada a $R$. brevifolia (Pohl) C. Ezcurra, pero se distingue por tener una corola más larga con un orificio más estrecho y una bolsa pronunciada en la misma, así como por presentar un hábito extendido y procumbente. Las diferencias y semejanzas de la nueva especie a otras en el género también son discutidas, y una clave actualizada para las especies bolivianas de Ruellia L. de flores rojas es presentada.

Key words: Acanthaceae, Andes, Bolivia, hummingbird pollination, IUCN Red List, Ruellia, Ruellieae, Ruellioideae, South America.

The genus Ruellia L. (Acanthaceae), with ca. 300 species, is particularly diverse in regions of western South America that host an impressive diversity of hummingbirds. It has been suggested that the diversification of some 330 species of hummingbirds began between 12 and 17 million years ago (Ma) and was partly driven by the Andean uplift (Bleiweiss, 1998a). This hummingbird diversity probably helps to explain species richness in some groups of plants (Bleiweiss, 1998b). One lineage in the Physiruellia clade of Ruellia (sensu Tripp, 2007; section Physi- ruellia Lindau) may be such an example. Centered on the widespread and morphologically variable $R$. brevifolia (Pohl) C. Ezcurra, this lineage contains at least 40 species (Ezcurra, 1989) that are distributed across portions of eastern Brazil, northern Argentina, Paraguay, Uruguay, Bolivia, Peru, Ecuador, and Colombia. A large portion of the species in this lineage, including the new taxon we discuss below, is adapted to pollination by hummingbirds. Among these species are $R$. chartacea (T. Anderson) Wasshausen, $R$. gracilis Rusby, $R$. haenkeana (Nees) Wasshausen, $R$. longipedunculata Lindau, $R$. pearcei Rusby, $R$. ruiziana (Nees) Lindau, and $R$. sanguinea Grisebach. Although species in this clade are morphologically distinguishable by both vegetative and floral traits, they show little genetic divergence, suggesting that the lineage may be young in age. A simple molecular clock approach estimated the most recent common ancestor of Ruellia to be approximately 9-14 Ma (Tripp, 2007), thus the age of this particular lineage may be even younger. It seems plausible that a mutualistic relationship with hummingbird pollinators, in combination with the Andean orogeny and other geological and climatological events, may have led to some level of diversification in one or both groups of organisms.

During fieldwork in 2000, a population of a redflowered Ruellia was discovered on the flank of a hill directly south of the Bolivian town of Rurrenabaque. The plants were initially identified as Ruellia ef. brevifolia, as this species is known to be common, widely distributed, morphologically variable, and shows the herbaceous habit of and approximately the same corolla size as the new population. Closer examination, however, revealed several striking differences from $R$. brevifolia, particularly in corolla morphology and growth form. Even though recent, regional taxonomic treatments are available for the genus in Bolivia as well as some surrounding areas (Ezcurra, 1993a, b; Wasshausen \& Wood, 2003, 
2004), the newly discovered plant was not among species known from Bolivia or other countries of southern South America. After a revision of the relevant literature and some 1000 specimens of Ruellia available to the second author, we concluded that the plant represented a new, undescribed species. The present paper describes the novelty and discusses its presumed relationships to other species of the genus.

Ruellia saceata Schmidt-Lebuhn \& E. Tripp, sp. nov. TYPE: Bolivia. Dept. Beni: José Ballivián Prov., abajo de una colina directo al sur de Rurrenabaque, $14^{\circ} 27^{\prime} \mathrm{S}, 67^{\circ} 32^{\prime} \mathrm{W}, 250 \mathrm{~m}$, 8 Sep. 2000 , A. N. Schmidt-Lebuhn 60 (holotype, LPB; isotypes, GOET, US). Figures 1, 2.

Haec species Ruelliae brevifoliae (Pohl) C. Ezcurra affinis, sed ab ea corollis ventraliter saccatis $23-30 \mathrm{~mm}$ longis ad orificium constrictioribus et habitu procumbente differt.

Perennial herb to ca. $50 \mathrm{~cm}$ tall; stems weakly erect, soon spreading horizontally and \pm procumbent, internodes 3-9 cm, glabrous. Leaves petiolate; margins subentire to weakly crenulate; petioles 0.5 $2.5 \mathrm{~cm}$, moderately pilose with white, untidily curved trichomes to $1 \mathrm{~mm}$; leaf blades ovate, 3.5-9.5 × 1.5$4.5 \mathrm{~cm}$, ca. $1.5-2.5 \times$ as long as wide, base broadly attenuate to rounded, apex attenuate, adaxially glabrous, abaxially glabrous except for scattered, straight, white trichomes along the veins and margins, these to ca. $0.25 \mathrm{~mm}$, cystoliths on both leaf surfaces, these simple, slender, ca. $0.2-0.5 \mathrm{~mm}$; secondary veins 5 to 8 on each side of the midrib, arching toward the apex, clearly visible especially abaxially. Inflorescences of cymes in the axils of leaves, only 1 per node of the main axis; peduncles $5-10 \mathrm{~cm}$; pedicels of subcymes ca. $0.3-2.3 \mathrm{~cm}$; inflorescences consisting of up to 10 flowers, peduncles and pedicels moderately pilose with somewhat untidily oriented, straight, white trichomes up to ca. $0.25 \mathrm{~mm}$; bracteoles linear, 1veined, $2-10 \times 0.5-1 \mathrm{~mm}$, pedicels $2-4 \mathrm{~mm}$, densely pubescent with straight, white trichomes up to $0.1 \mathrm{~mm}$. Flowers with calyces of 5 sepals, these green, subulate, 1-veined, 7-9 mm, basally connate, with the lobes $6-7.5 \mathrm{~mm}$ long, sepals densely pubescent with straight, white trichomes up to ca. $0.1 \mathrm{~mm}$, mostly eglandular with a few glandular; corollas $23-30 \mathrm{~mm}$, red, ventricose, moderately pubescent with straight trichomes and stalked glands to $0.2 \mathrm{~mm}$, the narrow unexpanded portion of corolla tube curved, 5-6 $\times 1-2 \mathrm{~mm}$, the expanded throat slightly curved, $15-20 \mathrm{~mm}$, its basal portion inflated to $12 \mathrm{~mm}$ with a pronounced ventral nectar-bearing saccus or pouch, throat constricted to $4-5 \mathrm{~mm}$ at the orifice, lobes emarginate, subequal, $2-3 \times$ ca. $2 \mathrm{~mm}$, appearing as a continuation of the throat; stamens with 1 pair to $1 \mathrm{~mm}$ longer than the other, filaments ca. $27-29 \mathrm{~mm}$, basally connate in pairs, with downwardpointing, mostly eglandular trichomes, these sparser to nearly glabrous on apical portions, some flowers with a dorsal staminode (i.e., representing a fifth stamen), adnate to corolla ca. $0.5 \mathrm{~mm}$ above filament fusion, staminode to $15 \mathrm{~mm}$, glabrous, fused filament sheath (curtain) adnate and enclosing nearly all of unexpanded portion of tube; anthers 2-thecous with equal, parallel thecae, purple, $2.5-3 \times$ ca. $0.6 \mathrm{~mm}$, level with the orifice of the corolla or exserted to $5 \mathrm{~mm}$, connective tissue of thecae glandular with very shortly stalked glands, pollen (Fig. 2) with reticulate exine, ca. $70 \mu \mathrm{m}$ diam.; ovaries densely puberulent and sparsely glandular with shortly stalked glands on the uppermost portion; styles purple, 30-32 mm, sparsely pubescent with straight trichomes and stalked glands ca. $0.1 \mathrm{~mm}$, stigma bifid, ventral lobe ca. $0.5 \mathrm{~mm}$ longer than dorsal lobe; capsules clubshaped, green with a dark reddish tinge at the tip and along the sutures when maturing, light brown when mature, ca. $12-16 \mathrm{~mm}$, the sterile portion ca. $5-8 \times$ 1-2 mm, the seed-bearing portion ca. 7-8 $\times 3-4 \mathrm{~mm}$, apex attenuate; ovules 12 per capsule; seeds dark brown, flat, ca. $2-2.5 \mathrm{~mm}$ diam., with hygroscopic trichomes restricted to the margins.

Distribution. Currently, only one population located on the western flank of a hill directly south of Rurrenabaque is known. Due to the inaccessibility of the site, little can be said about population size both in terms of number of individuals and area. At most, a few dozen plants were observed clustered in patches along part of the path, but it is conceivable that the population extends to inaccessible parts of the cliff, or even that more populations could be found in other parts of the poorly explored hill ranges on both sides of the Río Beni.

Ecology. The plants occupy very steep slopes and cliffs along a path following the water pipeline supplying Rurrenabaque, frequently rooting in cracks on the rocky cliff surface. The area is moist throughout the year, and the surrounding forest is semi-deciduous to evergreen. Conditions are relatively shady due to tree cover, but the plants seem to have an affinity for light gaps. Flowering time is at the end of the dry season, which extends from late May to September at the type location. Although no direct pollinator observations have been made, the shape, size, and brilliant red color of the corolla suggest that the plants may be adapted to pollination by hummingbirds. A nectar sample from Ruellia saccata included in a previous study (Schmidt-Lebuhn et al., 2007; as " $R$. aff. brevifolia") was relatively dilute with a concen- 


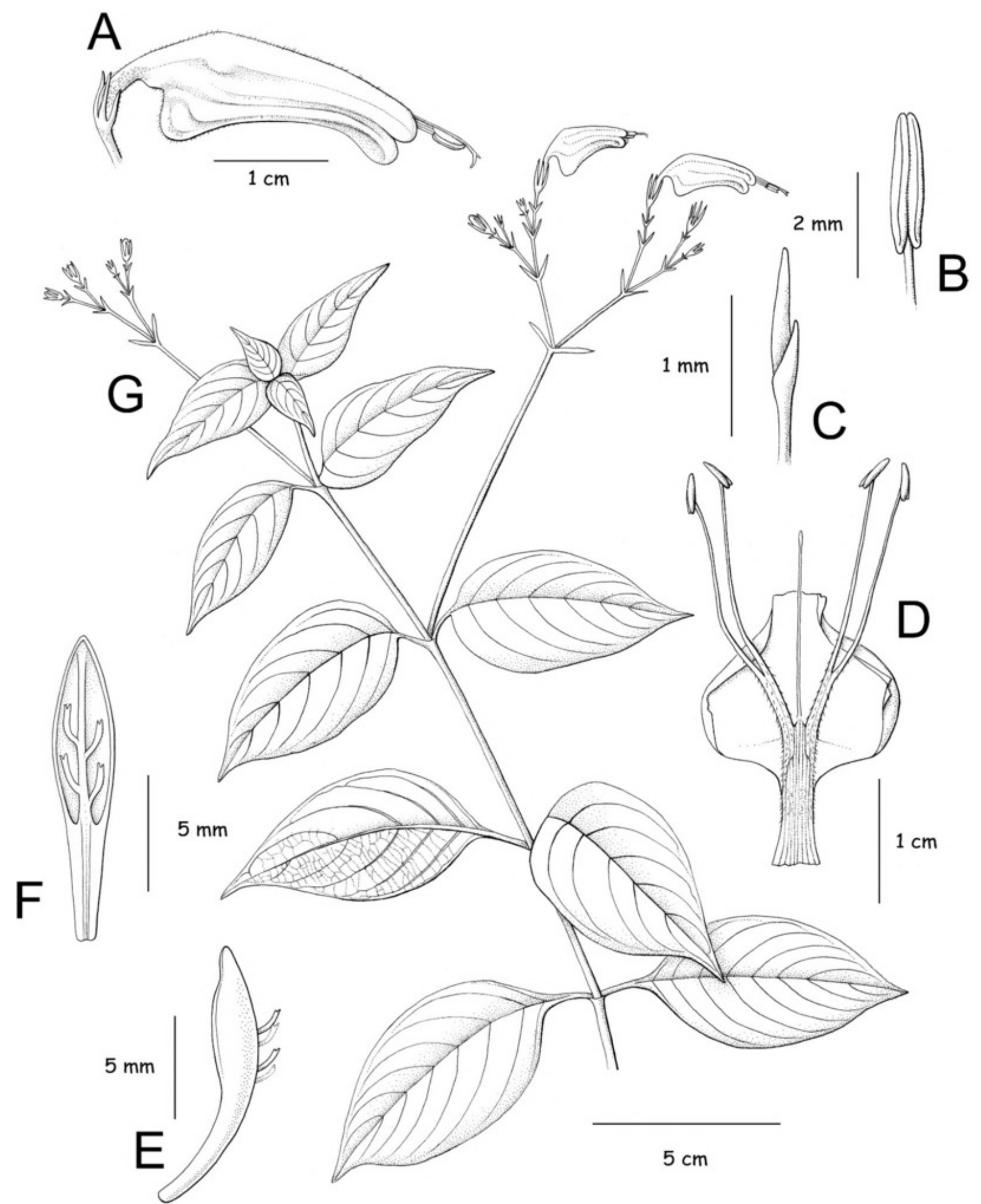

Figure 1. Ruellia saccata Schmidt-Lebuhn \& E. Tripp. - A. Corolla. - B. Anther. - C. Stigma. -D. Internal corolla surface shown with staminode (but note most corollas thus far examined are without staminodes). - E. External surface of capsule. -F. Internal surface of capsule showing one half of each of two locules. - G. Whole plant. Illustration by Amanda Labadie, drawn from the isotype A. N. Schmidt-Lebuhn 60 (US) and a corolla photograph of a live specimen taken at the type locality.

tration of $15 \mathrm{~g} / 100 \mathrm{ml}$ and contained mostly sucrose $(70 \%)$, thus showing a composition observed in many trochilophilous (hummingbird-pollinated) species.

IUCN Red List category. Due to the low number of plants observed at the type locality, only one specimen was collected, thus no paratypes exist.
The new species is therefore assigned a conservation status as Data Deficient (DD) according to IUCN Red List criteria (IUCN, 2001).

Etymology. The specific epithet describes the conspicuous, pouched protrusion or saccus evident at the base of the corolla throat. 


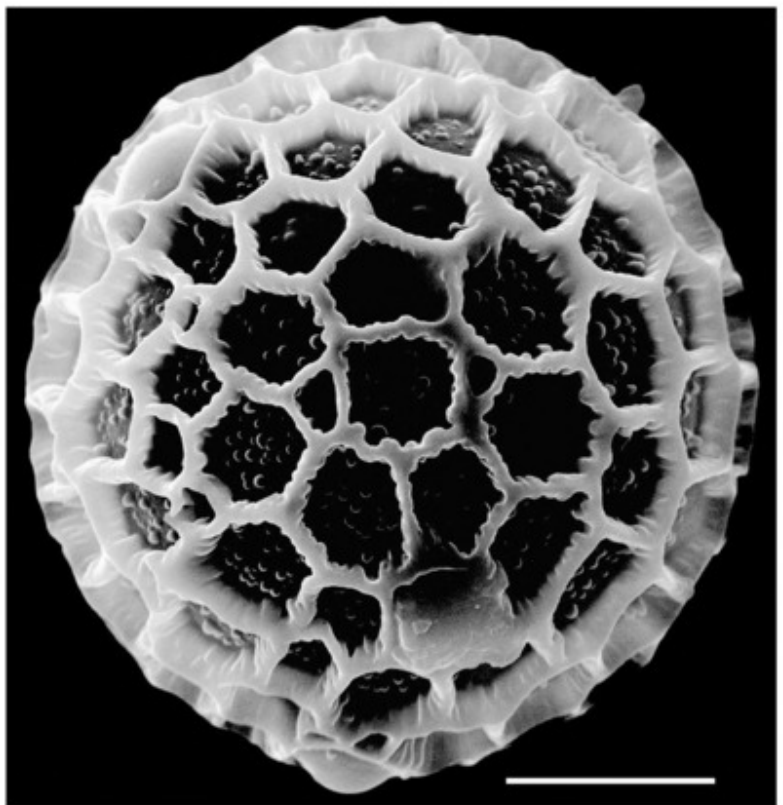

Figure 2. SEM image of pollen from Ruellia saccata. Scale bar $=20 \mu \mathrm{m}$.

Discussion. Ruellia saccata is notably similar to the widely distributed and variable $R$. brevifolia. Both species share the ventricose corolla with a very narrow basal tube and inflated throat, but the novelty is distinct by its pronounced ventral pouch and more constricted orifice (Fig. 1). In addition to corolla shape, $R$. saccata differs from $R$. brevifolia by its procumbent growth (vs. erect) and longer corollas (23$30 \mathrm{~mm}$ vs. usually up to $20 \mathrm{~mm}$ ). The tendency of the new species to grow horizontally is likely an adaptation to its habitat- the steep, rocky hillside that hosts the only population known to date.

Molecular data (E. Tripp, unpublished data) place Ruellia saccata in the highly derived and unresolved clade that is centered around $R$. brevifolia (Physiruellia clade; Tripp, 2007). In addition to molecular data, species in the Physiruellia clade of Ruellia are characterized by seeds with hygroscopic trichomes that are restricted to the margins (vs. covering the entire seed surface; Ezcurra, 1993b; Tripp, 2007). Ruellia saccata morphologically resembles other closely related species in this clade, including $R$. gracilis, $R$. pearcei, and $R$. ruiziana, especially with regard to herbaceous growth form and approximate corolla dimensions, color, and shape, especially the reduced lobes. It is again distinguished from these three species (and other red-flowered Bolivian Ruellia) by its remarkable corolla pouch as well as other features identified in the key below. The highly specialized corolla, with a very restricted orifice and the nectar-bearing pouch, is to our knowledge unique among New World Ruellia.
Another extraordinary feature observed in some flowers of Ruellia saccata is the occasional presence of a staminode that occupies the dorsalmost position in the flower and represents the fifth member of this whorl. It has been observed in two of 20 examined flowers. The presence of a staminode is remarkable in that most other species of Ruellia examined to date are known to have only four stamens (see Nees, 1847a, b; also, staminodes were recently discovered in multiple flowers in a population of $R$. bourgaei Hemsley in Jalisco, Mexico; see E. A. Tripp \& C. Kiel $428[\mathrm{RSA}]$. Staminodes are known from some of the remaining ca. 47 genera in tribe Ruellieae (e.g., see Wood, 1995, and Deng et al., 2006, for examples of staminodes in Strobilanthes Blume). Staminodes are known and can be common elsewhere in the family, in lineages outside of Ruellieae (McDade et al., 2000).

The key to (red-flowered) Bolivian Ruellia from Wasshausen and Wood (2004) is altered below to accommodate the novelty.

la. Corolla (excluding lobes) $41-60 \mathrm{~mm}$; lobes $>5 \mathrm{~mm} \ldots \ldots \ldots \ldots \ldots \ldots \ldots \ldots \ldots \ldots$

lb. Corolla (excluding lobes) up to $40 \mathrm{~mm}$; lobes $<5 \mathrm{~mm} \ldots \ldots \ldots \ldots \ldots \ldots \ldots \ldots \ldots$

2a. Corolla tube very gradually expanding from base, widest at opening of mouth; plant an erect perennial. ............. haenkeana

2b. Corolla tube abruptly expanding from base, widest in middle; plant a scrambling or vining perennial $\ldots \ldots \ldots \ldots \ldots \ldots$ inflata Richard

3a. Flowers solitary and subsessile or on short, leafy

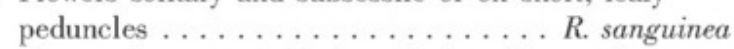

$3 \mathrm{~b}$. Flowers borne on richly branched, axillary peduncles that are devoid of leaves or leaflike bracts... . 4

4a. Leaves narrowly lanceolate to linear, $<1 \mathrm{~cm}$ wide . . . . . . gracilis

4b. Leaves broadly oblong, ovate, or lanceolate, at least $2 \mathrm{~cm}$ wide . . . . . . . . . . . 5

5a. Calyx lobes glabrous, oblong-lanceolate, usually $>$ $10 \mathrm{~mm}$ at anthesis . . . . . R R . longedunculata

5b. Calyx lobes pubescent or glabrous, long attenuate from base, $<10 \mathrm{~mm}$ at anthesis. . . . . . . . 6

6a. Corolla $31-40 \mathrm{~mm}$, gradually widened from base; leaves narrowly oblong-elliptic, often violet abaxially . . . . . . . pearcei

6b. Corolla up to $30 \mathrm{~mm}$, abruptly widened from a shortly cylindrical base; leaves variable but commonly ovate or elliptic, not violet abaxially . . . 7

7a. Plants weakly erect, spreading horizontally to procumbent; corolla clearly saccate, 23$30 \mathrm{~mm}$. . . . . . . . . . . . . Raccata

7b. Plants erect; corolla not saccate, rarely the back of the throat somewhat convex in $R$. brevifolia, $<20(-25) \mathrm{mm} \ldots \ldots \ldots \ldots \ldots \ldots \ldots \ldots . \ldots . \ldots$

8a. Leaves densely pubescent, at least $5 \mathrm{~cm}$ wide; inflorescence hirsute . . . . . . . . . R .

8 b. Leaves glabrous to weakly pubescent, $<5 \mathrm{~cm}$ wide; inflorescence glabrous to weakly pubescent . . . . . . . . b . . . . . Rifolia 
Acknowledgments. We thank the Bolivian authorities for the collecting permit that allowed for the discovery of this new species. The curatorial staff at GOET, LPB, and US made their duplicates available for study. We are grateful to Amanda Labadie for her careful illustration of Figure 1, to Tom F. Daniel, Cecilia Ezcurra, Lucinda A. McDade, Dieter Wasshausen, and John R. I. Wood for helpful discussions about the new species; to Uwe Braun for proofreading the Latin diagnosis; and to José Zúñiga for improving the Spanish abstract. Alexander N. Schmidt-Lebuhn's field trip in 2000 was partly funded by the Deutsche Akademische Austauschdienst (DAAD) and the Friedrich-Ebert-Stiftung (FES). Erin A. Tripp's lab and SEM work was supported by Duke University, Department of Biology, and a National Science Foundation Doctoral Dissertation Improvement Grant to P. Manos and E. A. Tripp (DEB-0608363). We are grateful for constructive criticism of an earlier version of the manuscript from John R. I. Wood and an anonymous reviewer.

\section{Literature Cited}

Bleiweiss, R. 1998a. Tempo and mode of hummingbird evolution. Biol. J. Linn. Soc. 65: 63-76. - 1998b. Origin of hummingbird faunas. Biol. J. Linn. Soc. 65: 77-97.

Deng, Y. F., J. R. I. Wood \& R. W. Scotland. 2006. New and reassessed species of Strobilanthes (Acanthaceae) in the flora of China. Bot. J. Linn. Soc. 150: 369-390.
Ezcurra, C. 1989. Ruellia sanguinea (Acanthaceae) y especies relacionadas en Argentina, Uruguay y sur de Brasil. Darwiniana 29: 269-287.

1993a. Acanthaceae. Pp. 278-359 in A. L. Cabrera (editor), Flora de la Provincia de Jujuy (República Argentina), Vol. 9. Colecciones Cientificas INTA, Buenos Aires.

- 1993b. Systematics of Ruellia (Acanthaceae) in southern South America. Ann. Missouri Bot. Gard. 80: 787-845.

IUCN. 2001. IUCN Red List Categories and Criteria, Version 3.1. Prepared by the IUCN Species Survival Commission. IUCN, Gland, Switzerland, and Cambridge, United Kingdom.

McDade, L. A., T. F. Daniel, S. E. Masta \& K. M. Riley. 2000. Phylogenetic relationships within the tribe Justicieae (Acanthaceae): Evidence from molecular sequences, morphology, and cytology. Ann. Missouri Bot. Gard. 87: 435-458.

Nees, C. G. D. 1847a. Acanthaceae. Pp. 9-164 in C. F. P. von Martius, A. G. Eichler \& I. Urban (editors), Flora Brasiliensis, Vol. 9. Weinheim/Cramer, Munich. . 1847b. Acanthaceae. Pp. 46-519 in A. P. de Candolle (editor), Prodromus Systematis Naturalis, Vol. 11. Treuttel et Wuertz, Paris.

Schmidt-Lebuhn, A. N., M. Schwerdtfeger, M. Kessler \& G. Lohaus. 2007. Phylogenetic constraints vs. ecology in nectar composition of Acanthaceae. Flora 202: 62-69.

Tripp, E. A. 2007. Evolutionary relationships within the species-rich genus Ruellia (Acanthaceae). Syst. Bot. 32: $630-651$.

Wasshausen, D. C. \& J. R. I. Wood. 2003. Notes on the genus Ruellia (Acanthaceae) in Bolivia, Peru and Brazil. Proc. Biol. Soc. Wash. 116: 263-274.

$\&-$ 2004. Acanthaceae of Bolivia. Contr. U.S. Natl. Herb. 49: 1-152.

Wood, J. R. I. 1995. Notes on Strobilanthes for the Flora of Ceylon. Kew Bull. 50: 1-24. 


\section{$2 \mathrm{BHL}$ Biodiversity Heritage Library}

Schmidt-Lebuhn, Alexander N. and Tripp, Erin A. 2009. "Ruellia saccata, a New Species of Acanthaceae from Bolivia." Novon a journal of botanical nomenclature from the Missouri Botanical Garden 19, 515-519.

View This Item Online: https://www.biodiversitylibrary.org/item/124658

Permalink: https://www.biodiversitylibrary.org/partpdf/121962

\section{Holding Institution}

Missouri Botanical Garden, Peter H. Raven Library

\section{Sponsored by}

Missouri Botanical Garden

\section{Copyright \& Reuse}

Copyright Status: Permission to digitize granted by rights holder Rights: https://www.biodiversitylibrary.org/permissions

This document was created from content at the Biodiversity Heritage Library, the world's largest open access digital library for biodiversity literature and archives. Visit BHL at https://www.biodiversitylibrary.org. 